\title{
DÜBLIN
}

Technological University Dublin

ARROW@TU Dublin

\section{The Civilizing and Sportization of Gaelic Football in Ireland: 1884-2009}

John Connolly

Dublin City University

Paddy Dolan

Technological University Dublin, paddy.dolan@tudublin.ie

Follow this and additional works at: https://arrow.tudublin.ie/clsart

Part of the Sociology Commons, and the Sports Studies Commons

\section{Recommended Citation}

Connolly, J. \& Dolan, P. (2010) 'The Civilizing and Sportization of Gaelic Football in Ireland: 1884-2008', Journal of Historical Sociology vol. 23, no.4, pp 570-98. doi:10.1111/j.1467-6443.2010.01384.x

This Article is brought to you for free and open access by the Centre for Consumption and Leisure Studies at ARROW@TU Dublin. It has been accepted for inclusion in Articles by an authorized administrator of ARROW@TU Dublin. For more information, please contact arrow.admin@tudublin.ie, aisling.coyne@tudublin.ie, gerard.connolly@tudublin.ie.

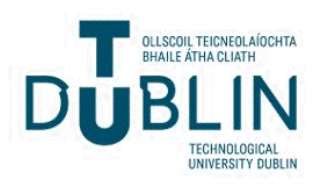


Authors: John Connolly and Paddy Dolan

Title: $\quad$ The Civilizing and Sportization of Gaelic Football in Ireland: 1884-2009

Originally published in Journal of Historical Sociology 23(4): 570-98. Copyright Wiley.

The publisher's version is available at:

http://onlinelibrary.wiley.com/doi/10.1111/j.1467-6443.2010.01384.x/abstract

Please cite the publisher's version:

Connolly, John and Paddy Dolan (2010) 'The civilizing and sportization of Gaelic football in Ireland: 1884-2008', Journal of Historical Sociology 23(4): 570-98.

DOI: $10.1111 / \mathrm{j} .1467-6443.2010 .01384 . \mathrm{x}$

This document is the authors' final manuscript version of the journal article, incorporating any revisions agreed during peer review. Some differences between this version and the publisher's version remain. You are advised to consult the publisher's version if you wish to cite from it.

Copyright (C) and Moral Rights for the papers on this site are retained by the individual authors and/or other copyright owners. 


\title{
The Civilizing and Sportization of Gaelic Football in Ireland: 1884-2009
}

\author{
JOHN CONNOLLY AND PADDY DOLAN
}

\begin{abstract}
Over the course of the last 125 years the sport of Gaelic football in Ireland has undergone a sportization and civilizing process as the rules governing the sport became stricter and players developed greater levels of self-control. However, the civilizing of Gaelic football was a particularly fragile and uneven process. The growing social desire to diminish displays of violence was moderated by ambivalence towards violence. Gradually the external social controls on players increased and, greater and more stable levels of internalization occurred reflected by more advanced levels of player selfrestraint in the control of violence. At the same time the threshold of shame toward displays of violence advanced. This transformation was shaped by lengthening chains of social interdependencies in Ireland.
\end{abstract}

\section{Introduction}

The purpose of this paper is to examine the issue of player violence within the sport of Gaelic football in Ireland over the last 125 years through the theoretical framework of Elias and Dunning (1986). We contend that the sport of Gaelic football has undergone sportization processes - the rules governing the sport have become increasingly standardized, more precise and comprehensive. In addition, the social constraints on player conduct advanced significantly and, in tandem with this, greater and more even levels of self-restraint developed, that is, a civilizing effect occurred, though this has been a particularly fragile and uneven process. By civilizing, following the work of Elias (2000), we mean that there has been movement in the balance between social and selfrestraint in favour of the latter concerning the control of violence; an advance in the threshold of repugnance for engaging in and witnessing violence; and the development of enhanced feelings of shame and guilt over player violence.

Yet, despite our main contention that the sport of Gaelic football has become "more civilized", violent incidents still occur in the modern game of Gaelic football and the sport is regularly criticized by journalists, social commentators, and some administrators of the Gaelic Athletic Association (GAA), the governing body for Gaelic football, for the persistence of violence and indiscipline. This raises several questions concerning our analysis and our overall contention that the sport has undergone a civilizing process. Recent studies of violence in sport examining the case of cricket led Malcolm (2001) to suggest that cricket may be undergoing a "decivilizing" spurt. We contend that this is not the case in Gaelic football however; based on our analysis, we argue that the civilizing of Gaelic football was a particularly uneven, fragile and slow process. The paper shows how the internalization of greater 
self-restraint was moderated by several intertwined social processes - the specific development of the Irish nation state and the role of violence in the successful, but incomplete, attainment of national independence; the symbolic alignment of Gaelic sports $^{1}$, 'physical Irish manliness' and nationalism; the development and intensification of local and regional sporting rivalries representing different "we-group" identities; and the relatively even power ratios between the different units comprising the GAA. Despite these moderating effects, a civilizing process did occur and although transgressions and violence can and still erupt, these are generally of a more controlled and muted nature illustrating a transformation in the manifestation of violence, broadly reflecting a shift in balance between spontaneous transgressions towards more instrumental transgressions.

\section{Elias and the Civilizing Process}

Here we briefly explain the central aspects of Elias's theory and some of the key concepts. Elias (2000) argued that in the course of civilizing processes, which occurred in West European societies ${ }^{2}$, standards of social and self-control were transformed, particularly in relation to violence and bodily functions, as were people's attitudes and feelings toward displays of violence - the threshold of repugnance towards violence and its display advanced, and the balance between social and self-restraint shifted in favour of the latter as people came to exercise more even and stable self-controls. Central in explaining these changes in the expression and control of violence, more generally, and in this case within the sport of Gaelic football, is an understanding of what Elias terms figurational shifts. For Elias the concept of figuration is a means of orientation for studying people in dynamic interdependent relationships (in processual interdependence). A key principle within Elias's theory is that all social life is in constant motion, in process. Figurations, then, are nothing other than fluid networks of interdependent people with different and shifting power balances between the people comprising them. Thus, it is figurational dynamics, changes in the tension balance and dependency ratios (power balances) between people comprising a figuration, that can explain social developments, such as the formation of nations and organizations, the emergence of new tastes or practices, and changes in attitudes towards violence. Elias's main thesis is that where a stable state monopoly of violence is achieved, it facilities more extensive and interwoven functional differentiation and specialization - that is lengthening chains of social interdependence. Both these process, the state monopolisation of violence and increasing interdependency exert civilizing pressures.

The state monopolisation restricts and punishes those who engage in violence. Lengthening chains of social interdependency also exert a civilizing effect because, for expanding and differentiated functions to interlock at some level of cohesion, people must adjust and adapt their behaviour and employ greater levels of all-round selfrestraint in their daily lives. In effect, a pressure develops for people of more, and varied, class dispositions to exercise greater self-control over their emotions and actions. More people are dependent on others to meet and satisfy a greater number of their needs, so a greater social constraint towards stricter self-constraint develops - a 
civilizing effect occurs. This movement from social constraint toward greater selfrestraint means the individual's conscience becomes more important as a regulator of one's behaviour (Sheard, 1999, p. 181). Gradually, over time, these emerging standards become the norm until they too are replaced under the compelling pressure, emanating from further advances in social interdependency, for greater self-restraint, though, it must be noted, such processes may not be linear and may also go in reverse (Elias, 2000, p. 445). As these latter social standards, or normative expectations concerning self-restraint, were gradually internalised, in turn they became a second nature habit into which younger members of society were socialized. So what at one time was considered acceptable conduct becomes, in a later period, or generation, perceived and characterised as uncontrolled or disgraceful behaviour. This process of social development, which is neither linear or even, is reflected in different aspects of all social relations, such as sport, as "no sport can be insulated from the wider society in which it is played" (Dunning \& Sheard, 1979, p. 175).

\section{A Developmental Approach to Violence in Sport}

Elias's theory of civilizing processes has been applied as a frame of analysis for a range of sport studies concerning the control of violence - rugby football (Dunning \& Sheard, 1979), association football (Dunning, 1999; Dunning, Murphy, \& Williams, 1986), boxing (Sheard, 1997, 2004), cricket (Malcolm, 2001) and hurling (Dolan \& Connolly, 2009). While, some recent figurational studies fit closely with Elias's original ideas, others have digressed and have not adopted a developmental approach in addressing questions of violence in sport. The approach taken here, like that of Malcolm (2001), stands in sharp contrast to many sociological investigations of sport more generally, but also including some figurational-sociological studies, which focus attention on the present or recent past; this somewhat evokes Elias's (1987) concern regarding the retreat of sociology into the present. This trend, particularly within figurational-sociological studies of sport (see Elliott \& Maguire, 2008, for example), fails to recognize the longterm processual and dynamic nature of figurations. Although Elias (1978) argued that long-term developmental studies were particularly useful in illustrating and explaining change, a considerable feature of many recent figurational-sociological studies of sport (see Liston, 2005; van Bottenburg \& Heilbron, 2006) is a relative de-emphasis of historical figurational shifts. In the case of Gaelic football, a developmental approach allows us to explain how and why current expressions of violence within Gaelic football have changed; how violence was and is socially defined; and how shifts in the balance of power between groups comprising Irish society and comprising the GAA have shaped such change. More specifically, within the context of debates about violence in the sport of Gaelic football, the study of longterm social processes can distinguish between what one might perceive as a decivilizing spurt and what is in fact a complex structural aspect within a wider civilizing trend, what Dunning (1986b) has referred to as a change in the balance between affective and instrumental violence. 


\section{The Early Development and Codification of Gaelic Football}

Gaelic football is a field game involving two teams of fifteen-a-side. Each team has a goalkeeper as in soccer and the goal posts resemble the $\mathrm{H}$ structure as in rugby football, while the playing surface is wider and longer than of either soccer or rugby. The object of the game is to propel the ball over the cross bar and between the posts for a score (one point) or under the cross bar and between the posts for a goal (three points). The ball can be kicked, fisted or caught "in the air". The main organizational basis for the nascent standardization of Gaelic football like its sister sport, hurling3, began with the establishment of the Gaelic Athletic Association (GAA) in 1884 (De Búrca, 1989, p. 71-99). Games of football similar to the folk football played in Britain (see Dunning 1999, p. 83-88), also appears to have been played in Ireland (Mahon, 2000). These games differed slightly from region to region (see Hunt, 2008, p. 155; 0'Donoghue, 1987, p. 36-37). For instance, in the south-west of Ireland a football game, known in the Irish language as "caid" was played, which appears to mirror the English folk version of football with the ball thrown in on parish boundaries and played throughout the day (Guiney, 1976). Prior to the formation of the GAA (and for a considerable time afterwards) Gaelic football games were mainly localised affairs with considerable variation in how the sport was played in different regions (see Hunt, 2008, p. 154).

The desire to standardize and enforce the rules by a central body culminated in the codification of the game at a national level in 1884. The rapidly growing number of new GAA clubs (Mandle, 1987, p. 31) and the formation of inter-club competitions involving teams of greater geographical distance advanced the need for social coordination to a standardized set of rules. Despite this early attempt at standardization many games were abandoned due to opposing teams playing under different rules and unable, or unwilling, to adjust their play in accordance with the play of their opponents or the national rules. The potential for confusion was augmented by the fact that in Ireland Gaelic football was played alongside the English football games of soccer and rugby. Indeed, many Gaelic football teams were originally teams that competed in these sports, and in the early years many teams continued to play under the different codes. For instance, The Celtic Times (April 16, 1887, p. 7) reports that C. J. Kickhams (a Gaelic football team from County Waterford) "hold an unbeaten record under the Gaelic, Rugby, and Association rules". In addition, the GAA, in attempting to establish a national sport of Gaelic football and gain a competitive edge over rival sports such as rugby, sought to distinguish its football rules from rugby and soccer at an early stage. The Gaelic football rules of 1889 note the ball could not be carried or thrown (Lennon, 1997, p. 33) (which is a feature of rugby), and this rule became even more precise by 1896 stating that carrying was taking more than four steps (Lennon, 1997, p. 52).

Despite this, many games were often played according to rugby rules, or a combined version of Gaelic and rugby rules (see Hunt, 2008, p. 154). In the late 1800s Gaelic football resembled a type of play that had as much in common with rugby as with contemporary Gaelic football. Scrummages and headlong rushes were commonplace and games could involve ball-carrying, while tripping, wrestling and handigrips were 
practices not only engaged in by many players, but were in fact allowed within the established rules of that time (see Celtic Times, October 29, 1887, p. 3).

While Gaelic football was a distinctive game from either rugby or soccer there were certain similarities in play, which understandably led to confusion with some teams playing Gaelic football under some of the rules of soccer or rugby. Indeed in some contests players in Gaelic football matches often resorted to rugby type play, which led in many cases to teams abandoning matches on account of their opponents refusing or being unable to play under the rules of Gaelic football (Celtic Times, May 21, 1887, p. 8, June 4, p. 3). Although many players, as a second nature reaction, adopted aspects of play associated with rugby or soccer during Gaelic football matches, the GAA was anxious to differentiate Gaelic football through the rules and structure of the game. Thus, rule standardization was not just a means of standardizing the playing of Gaelic football across the country under one set of rules, but was also a means to eliminate aspects of the rugby game from Gaelic football. Gradually, though, teams began to adjust their accustomed tradition of play in accordance with the national rules.

\section{Violence in the Early Years}

In the formative years of the GAA outbreaks of fighting between players on opposing teams, as well as violence between players and spectators, appears to have occurred quite frequently. Testimony to the scale and extent of this violence can be found in the match reports of that time with recounts of frequent stoppages and the regular abandonment of matches owing to violent disturbances and disorder (see, for example, Celtic Times, March 5, 1887, p. 3; May 21, 1887, p. 6; July 9, 1887, p. 6; September 10, 1887, p. 5, p. 7; October 1, 1887, p.7). Many of these reports refer to the enhanced levels of excitement experienced by players and supporters alike during outbursts of fighting. Such emotional volatility was not merely characteristic of the sport of Gaelic football but also related to the general capriciousness of life at that time (see, for example, Conley, 1999, pp. 57-72).

Faction fights ${ }^{4}$, still a feature of Irish life, sometimes overlapped Gaelic football matches (see, for example, Garnham, 2004, p. 76; Irish Times, July 23 1890, p. 6). These confrontations often resulted in severe injury, and in more extreme cases, death: During a Gaelic football tournament on Sunday William 0 Connor, aged 21, one of the players, was assaulted by some members of the opposing team, and knocked down. A man then stabbed him through the heart with a knife causing instant death. (Irish Times, August 29,1893, p. 5) Serious injury and death also occurred unconnected with faction fights (see Nolan, 2005, p. 59) demonstrating the physical nature of the contests. Writing some years later in 1914, one Gaelic footballer claimed that the sport in those early years was no more than a game of "the rough-and-tumble ... [where the] go-for-theman system obtained" (Fitzgerald, 1914, p. 13; see, also, McTernan, 1984: 82, for a similar account). The physical and attritional nature of Gaelic football contests at that time can also be discerned from the fact that wrestling and "handigrips", and the practice of "scrimmages" and/or "scrummages", were part of the sport. Newspaper accounts of the time (Celtic Times, June 9, 1887, p. 6, September 3, p. 3, 
November 5, p. 6, December 17, p. 6) suggest that this practice involved large numbers of players attempting to move the ball forward, while simultaneously resisted by players from the opposing team, indicating strength and weight counted considerably, a conclusion also drawn by McDevitt (1997). The large number of players on each side (up to twenty one) also contributed to the crowded and congested nature of many fixtures. Furthermore, matches were played in the winter season in fields with deep grass (Hunt, 2008), all of which contributed to slow physical contests. Wrestling and handi-grips were prohibited within the sport in the 1886 rules (Lennon, 1997, p. 24), but not without resistance from some GAA members who sought to retain the status quo; they considered the decision "subversive of the Gaelic rules" (Ó Riain, 1994: 101). Despite the prohibition, matches continued to involve "wrestling" of some form for a time afterwards. For instance, a match report in the Celtic Times (March 5, 1887, p. 3) ${ }^{5}$ states: The match was played under the G.A.A. Rules, but wrestling was allowed. Many of the members of the home team committed fouls, but no notice was taken of them. It would be much better if the rules were strictly adhered to, both on this and other points.

Much local contingency still remained as the newly codified rules were not diffused to all parts of the country (see, for example, Hunt, 2008, p. 154). In addition, players were unwilling to adhere to the rules and accept the interpretations and decisions of referees. Newspaper reports of the time regularly indicate matches finishing prematurely as players refused to continue playing owing to such disputes (Celtic Times, May 21, p. 7, 8; Hunt, 2008, p. 149). To address this, the rules were amended in 1895 to include the sanction of suspension and forfeit of the match for teams leaving the field without the permission of the referee (Lennon, 1997, p. 45). Violence was also inter-related with these on-field disagreements between players and officiating functionaries. In these circumstances some referees appear to have been unwilling or reticent about enforcing the rules, particularly in relation to 'disqualifying' or sending-off players. Indeed, one GAA county committee in 1894 added bye-laws to the national rules to address this problem: "No player once ordered off the ground by the Referee shall under any circumstances be allowed to join again. The ridiculous custom of giving offenders a couple of minutes rest shall be discontinued" (Lennon, 2001, p. 41).

Gradually the powers of control and the sanctions available to referees increased, illustrating the declining tolerance toward violence and indiscipline. Efforts to curb breaches of the rules saw the introduction of the free kick as a sanction in 1888 (Lennon, 1997, p. 26). Indeed, by 1896 there were twenty-seven rules compared to only ten in 1884. Further evidence of the advancing threshold of repugnance can be seen in the attempts to address the problem of verbal and physical assaults on referees with the introduction in 1896 of a sanction of twelve months suspension for threatening or insulting the referee (Lennon, 2001, p. 51).

Despite these attempts to quell both the threat of, and actual, physical assault outbreaks of violence remained within the sport. Eruptions of on-field violence were sudden and often escalated in a spiralling cycle with other players and spectators 
joining the affray. This reflected the emotional volatility of people at that time, when emotions and feelings were vented more freely. For example, one journalist, most likely Michael Cusack, one of the founding members of the GAA, describing a match in 1887 as involving "strong rough play, with an occasional push from behind, and a free indulgence in handigrips", expressed the view that: The toleration of this kind of play by the referee in charge is a thing that cannot be too strongly deprecated. It has the effect of stirring up the passions and jealousy of men who are naturally hot-tempered, and individual manly pride will endeavour to assert itself, in some instances, by the use of knuckles. (Celtic Times, September 10, 1887, p. 7)

This portrayal gives an indication of the standard of emotional control expected of players at the time, where the balance between self and social control lay firmly toward the latter. While the players in the above account were criticised for their behaviour, the general expectation was that in physical sporting contests men would lose their temper and engage in violent confrontations and this was to be dealt with by strict external (social) controls. Yet the threshold of repugnance toward violence did advance as seen in the attempts to further protect players from physical violence - an indication of a lower tolerance for violence. An example of this was the protection extended to goalkeepers within the rules. Goalkeepers had been particularly vulnerable to physical assault, even by the early 1900s, as a practice had evolved in which they were either struck and/or taken out of the play by opposing players before the arrival of the ball in the goalmouth area as attacking players sought to garner a scoring advantage. The GAA authorities sought to address this in 1908 with the inclusion of a parallelogram in front of the goal, where no player from the opposing team was allowed to enter until after the arrival of the ball (Lennon, 1997, p. 66). Indeed, the rule changes of 1908 were considered by one prominent GAA official at the time of imposing "a very considerable constraint on players as compared with former times" (Gaelic Athletic Annual and County Directory, 1910-11, p. 58-61). There was also growing intolerance for players abandoning matches following a disagreement over a referee's decision as evidenced by the increase in the severity of the penalty for this indiscretion to a six month suspension in 1912 rules (Lennon, 1997).

\section{The Ambivalence Toward Violence}

Despite the expansion in the number of rules and the increased severity of sanctions, the problem of teams abandoning matches continued into the early part of twentieth century, as did eruptions of player violence (see Gaelic Athlete, 1908-09, p. 42). This illustrates the fragility of the internalisation process - of internalising higher standards of affect controls over one's behaviour. At one level the GAA authorities sought to eliminate violence within the sport, yet, simultaneously, they not only espoused the virtues of physical and manly strength, but in fact made reference to the military function of Gaelic games through descriptive metaphors (Celtic Times, February 19, 1887 , p. 5, 6, February 26, p. 4,5, June 18, p. 7; McDevitt, 1997, p. 262-284) and in the organization of training and tactics (McDevitt, 1997, p. 268). Since the initial attempts in the 1880s to form a "Gaelic" athletic organization, early supporters of the GAA began to 
convey a link between the GAA and "Ancient Ireland" where Ireland and the "Gaelic" Irish race were viewed "as synonymous with bravery", and Gaelic games were conflated with preparation for war (Celtic Times, February 19,1887, p. 5). As such, the GAA was connected to cultural narratives espousing Irish nationhood (see Gaelic Annual, 190809, p. 6). Consequently, efforts by the GAA authorities to curb violent and aggressive play were in juxtaposition to the valorisation of "Gaelic" men for their physical prowess and for the wild and dangerous games they played. The imposition of social constraints existed simultaneously with a contradictory narrative advocating the natural warlike and dangerous nature of not just Gaelic games but Irishmen too. This was also a social compulsion on players to embody these characterisations. Thus, to an extent, this moderated the inculcation of more extensive and stable self-control drives, and the development of more pronounced feelings of guilt and shame toward the use of violence.

The veneration of both Gaelic players and the sport of Gaelic football for its wild and physical nature was connected with the wider social context in Ireland at that time. As the social tensions escalated between the different ethnic groups in Ireland, the sports played in Ireland underwent a socio-symbolic realignment; rugby, cricket and tennis became increasingly unacceptable for the "true Gael". The British, or more specifically English, games were positioned in direct opposition to Gaelic football, which had taken on a particularly national and patriotic identity. The GAA sought to promote native Irish games to refute British influence symbolically, a conclusion also drawn by McDevitt (1997). Gaelic football was characterized as a masculine and warlike pastime as opposed to the lesser effeminate English games. This we-image (Elias, 1991, p. 155233; Mennell, 1989, 367-233) of the true Gael (the outsiders), powerful, wild and manly, includes (and accepts) what the British (the established) (Elias \& Scotson, 1994) say about their inferiority - the wild, uncontrollable Irish - a caricature of the Irish which was common in the nineteenth century (Cronin, 1998).

Thus, there was also a felt need among Gaelic players to embody this British characterisation, which shaped and enhanced the ambivalence towards violence (Dolan \& Connolly, 2009). In this developing social context with tensions rapidly escalating between Irish nationalist groups on the one side and British and Irish unionist groups on the other, Gaelic games, for some players, became an actual preparatory mechanism for warfare and the mimetic function of Gaelic football receded. In 1913 and 1914 county units of the GAA endorsed motions to establish rifle clubs to train an army (see, for instance, Mandle, 1987, p. 162), while Gaelic players also trained with the Irish volunteers ${ }^{6}$. With the relative success of violent uprisings in the establishment of an "independent" Irish state following the military conflict between Irish and British forces during 1916 and later during the War of Independence (19191921), the ideology of violent conflict took on positive emotional associations for many Irish people. The connection of manliness with Gaelic games and the historical legacy of successful armed conflict was embodied in the playing of Gaelic football and served to moderate civilizing pressures. 


\section{Toward Greater Self-Restraint}

Certainly by the late 1920s and early 1930s physical violence was still a considerable problem within the sport and there are numerous reports of physical assaults on referees in national and regional newspapers of the day (see Connacht Tribune, October 10, 1931, p. 27; Irish Times, April 13, 1936, p. 8). Between 1927 and 1929 we identified three cases where players died during Gaelic football contests from injuries received during matches. In two cases players were later charged with manslaughter (see Irish Independent, May 17, 1927, p. 8; Irish Times, June 21, p. 9). However, the social constraints to which players were increasingly subject were gradually reflected in changes to player behaviour indicating that many players were exerting greater selfcontrol over their on-field conduct. One well known sports journalist of the day known as "Carberry" suggested in the Gaelic Annual of 1927 that "malpractices and displays of temper on the playing fields have disappeared" (p.8). This may have been an attempt to demonstrate the "progress" of Gaelic games by a sympathetic journalist, as it was clearly not the case that violent incidents no longer occurred. But, perhaps, it was indicative of an overall improvement in player behaviour. Several other factors tend to support this contention. First, other journalists of the day also reported improvements in player discipline and "self-control", (see Irish Times, April 28, 1933, p. 13), while also noting the decline of indiscipline "even in remote areas" (Irish Times, January 22, 1936, p.4). Similar sentiments were also expressed by the then GAA president (see Irish Times, April 13, 1936, p. 8).

Second, although numerous assaults on referees and players can be identified, at inter-county and inter-club level there is considerable evidence that the threshold of repugnance toward displays of violence had advanced considerably. For instance, many county committees not only condemned violence, but systematically imposed suspensions for either threats to, or violent assaults on, referees and players. Following a match in 1935 between the county teams of Armagh and Fermanagh, a member of the Armagh county committee, at a meeting a week later, chastised his own county's players for their on-field behaviour, claiming it "was simply disgraceful and disgusting and was degrading to the game". The same individual then moved a resolution "that J Donaghy, J Harney, J McSherry [Armagh players] be asked to attend next Co Board mty [meeting] to account for such conduct and show reason why they should not be suspended for the same" (Minutes of Armagh County Committee, July 14, 1935). This report is significant in light of the fact that there was a tendency by officials of clubs and county committees to instigate objections and support their own players arising from disciplinary sanctions.

This suggests here that some officials were increasingly unwilling to condone certain practices indicating that the threshold of repugnance was advancing. A further indication is the advancement in punctuality which appeared to have improved by the 1930s, with newspaper accounts noting progress in player punctuality (Irish Times, December 23, 1936, p. 10) and in the overall organization of games, as championships increasingly finishing on schedule. The fact that such issues were written about would suggest firstly, that prior to this, players and teams tended to be unpunctual and secondly, that expectations regarding punctuality had now increased throughout 
society at that time. By 1943 for instance, the rules stated that should a match be postponed for some unavoidable cause, it may be refixed for a date seven days later (Lennon, 1997, p. 205), indicating that teams (and individuals) must be more certain of being able to turn up to play. These were relative movements concerning the increasingly felt need to be "on time". Elias (1993) argues that this growing pressure to be punctual reflects the lengthening chains of social interdependencies and the tighter interlocking of functions and actions; people gradually learn to time their activities in relation to the timed activities of other people upon whom they depend. Simpler social networks with fewer and shorter links of mutual dependence produce laxer standards of punctuality compared to more complex figurations. The imposition of more extensive social control on players was facilitated by advances in the level of integration and centralization of the GAA. By 1909 every county in Ireland had a county committee affiliated to the Central Council of the GAA (Carey, 2007).

However, while these changes represented a degree of advancement in the centralized authority of the GAA, it still remained a relatively uneven and fragile process. Throughout the 1920s (see Devine, 2002, p. 24-33) and up to and including the 1940s, many of the organization's subunits refused to accept decisions of the organization's centralized authorities and also sought the decentralization of decision making (see GAA, 1943). Yet, the gradual centralization of administration facilitated the GAA authorities in imposing stricter and more expansive controls over player discipline through rule standardization, more consistent rule implementation, and greater social surveillance of play through the appointment of impartial referees and other officials specializing in the application of fair play. In turn, this too facilitated a further shift in the power balance between players and regulating officials. As referees were given greater on-field powers and supported off-field by the imposition of suspensions on players, the power ratio between players and referees shifted further in favour of referees.

Several rule changes also reduced the physical nature of sport. In 1884 the rules specified that the number of players a-side should be not less than fourteen and no more than twenty one (Lennon, 1997, p.10). By 1895 it was reduced to seventeen a-side and by 1910 to fifteen (see Lennon, 1997). Less numbers meant greater space for player movement by making games less congested. This in turn facilitated the development and specialisation of particular practices such as kicking, catching, player movement and positioning on the field. For instance, in 1914, the book Catch and Kick, written by County Kerry footballer Dick Fitzgerald was published which was essentially amanual on how to play Gaelic football. Fitzgerald (1914, p. 13-15) suggested the game was no-longer a "a trial of strength and endurance", but instead "more a trial of skill" where "[e]ach player is taught to see the advantages of combining with everybody else on his side, and of playing at all times unselfishly".

The game too underwent a rationalization process in relation to the commencement of the game and in the prescription of player positions. Initially, all players with the exception of the respective goalkeepers would line up side-by-side and the referee (and later, for a period, clergy men or dignitaries) would throw in the 
ball between the two requisite lines of players. This was gradually reduced to two from each side by the 1966 rules (Lennon, 1997,p.268), suggesting the heightening significance of structural positions on the field of play. Player positioning though not only changed as a result of rule changes put also as a result of player experiences of previous games and the intended expectations of their opponents. This too demonstrates how players were exercising greater foresight and self-regulation in the playing of Gaelic football.

All of this suggests a movement in the direction of exercising greater selfrestraint, and an advance in the threshold of repugnance toward violence within the game. Yet it is important to point out that these developments were both gradual and uneven. The social class makeup of specific teams (people of a higher social class disposition tend to exert higher levels of self-restraint and control) would for instance explain differences in the readiness for, and in the expression of, violence that existed between different social groups. Also, the intensity of relations between clubs and counties due to the narrow, yet strong, feelings of identification toward one's team, which in turn often to led to bitter rivalries and violence during fixtures, moderated civilizing tendencies to a degree in specific regions. For instance, in the Tyrone County final of 1944 the referee was attacked by players and supporters of the defeated team (Moortown). In his report he stated: I was immediately surrounded by about 6 Moortown players. They held me firmly by the throat, and at least two of them hit me. At this moment a crowd rushed on the field, and with my throat still in this human vice I was beaten, kicked. (Minutes of Tyrone Co. Committee, October 12,1944)

It is clear from media reports and the minutes of GAA organizational and disciplinary units, such as the above, that both players and referees continued to be subject to physical assaults in the 1940s. However, the reaction of the authorities to such incidents indicates that the threshold of repugnance towards violence had advanced. For instance, in the case above, the Moortown club was suspended for five years and several of its members, players and supporters, suspended from the GAA for life. Neither was the severity of these sanctions exceptional. For example, following the All-Ireland Final of 1943, in which match officials were physically assaulted (Courtney, 2005, p. 17), several players were suspended for twelve months and one player banned for life (Anglo-Celt, October 30, 1943, p. 10).

The regulation of indiscipline and violence was sustained at a certain level by socially induced self-restraints but also by high levels of external control. This reflected the belief at the time that players were prone to sudden inclinations and impulses during matches, and that, naturally, they would find it difficult to exert strict selfregulation of their behaviour. For example, following several reports of assaults on referees by players in 1936, the then GAA president stated that the players involved "may not have averted to the extreme gravity of their conduct" (Irish Times, April 13, 1936, p. 8). Though the players are condemned, the pronouncement is relatively forgiving of the players. In contrast, journalists and officials implored referees to take sterner action and strictly apply the rules indicating that external control was perceived as the primarily means of instilling discipline (see Lennon, 1999, p. 700; Gaelic Athletic 
Annual 1934-35, p. 9; Irish Times, December 23, 1936, p.10; Irish Press, September 27, 1938, p.12, July 23, 1946, p. 8).

Yet alongside calls for the application of stricter rules and heavier sanctions within the sport, physical strength and bravery were still valorised. This, and the intensification of local rivalries or the emergence of new ones, and the fear of loss in such contests, acted as a counter force to civilizing pressures. The bitterness expressed on the field was often reflected off-field in administrative and organizational disputes between clubs, between clubs and county committees, between different county committees, and between county committees and provincial councils (see, De Búrca, 1999, p. 140). Therein lay certain ambivalence toward addressing on-field violence. The relatively fragile nature of on-field self-control was often replicated in the off-field obstinacy and refusal to accept disciplinary decisions against particular players or teams. For instance, arising from the violent disturbances which occurred during the 1943 All-Ireland final, noted previously, the regional newspaper from one of the counties involved expressed indignation at the "severity" of the suspensions imposed. The unnamed journalist suggested the twelve month suspension was "most unreasonable" (Anglo-Celt, October 30, 1943, p. 10). These contradictory processes explain the slowness, fragility and uneven nature of the internalization process concerning self-control and self steering.

\section{The 1960s Onwards}

Further evidence of the slowness of this process - the internalization of stricter control of impulses and emotions - can be seen from the debates between GAA officials over proposals to expand the social scrutiny of players. Although linesmen were encouraged to call attention to "rough or foul play" under the 1896 rules (Lennon, 1997, p. 49), it did not become an established feature of the game; players were unwilling to abide by the decisions of linesmen. Such a view persisted up to the 1950s and was in fact enshrined within the regulations where the sole duties of linesmen (the officials expected to run the line following the play pitch-side) were to denote where the ball had gone over the sideline and which team was entitled to the kick (or throw) ${ }^{7}$ from the sideline ${ }^{8}$. In 1955 a motion at the GAA's annual congress to increase the social observation of players by empowering linesmen and umpires to report any serious breaches of the rules which may have escaped the referee was rejected (April 10, 1955). One member of Congress (S. De Barra) suggested:

This is a dangerous motion I would not like to be the linesman in a serious Championship who would call over the referee when the ball was up the field.

Suppose the referee did not see the signals of the linesman? There would be civil war on the grounds if you had such a rule. (GAA, 1955)

This example illustrates that many GAA officials believed such a rule was unworkable owing to the inability of both players and spectators to control their behaviour if decisions were seen to be made against their team, particularly by social functionaries 
other than the referee. The expectation of self-control in such situations within the debate is notably muted. However, by the early 1970s the linesmen and umpires were given the power to draw the referee's attention to incidents of rough tactics or deliberate striking, hitting and kicking, which may have gone unnoticed by the referee (Lennon, 1997, p. 288).

These changes reflect not only the increased social scrutiny of players but also changes in the beliefs and expectations concerning the control of violence. The introduction of the above mentioned rules widening the powers of linesmen and umpires occurred without any concern being expressed over the ability, or inability, of players or spectators to abide by the proposed amendments, illustrating that expectations and fears of disturbances owing to such decisions had diminished. This indicates the socially accepted level of self-restraint expected of people had advanced. This advance is particularly perceptible from the 1960s onwards. An analysis of the rules during this period indicates greater precision in defining and classifying tackling so as to identify and penalize what was considered "rough play". While this is indicative of a heightened sensitivity toward violence and injury as the type of tackling legitimised becomes more precise and less open to interpretation, it also illustrates a growing expectation for higher levels of self-control, as players are required to develop more nuanced methods of tackling to abide by more precise rules. For instance, a "fair charge" was defined in 1966 as "shoulder to shoulder" and by 1975 as "side to side with at least one foot on the ground" (Lennon, 2001P, 269, 307). Thus, the social compulsion for players to check their behaviour in conducting a legitimate tackle increased further. Expectations surrounding how to control indiscipline and violence also reflect the increasing social pressure for greater regularity in self-control. For example, in the GAA's Strategic Review, published in 1971, dealing with various aspects of the organization, the section on discipline states:

There is, we fear, an increasing tendency to depend on the Referee to impose proper standards of sportsmanship and good behaviour on players. This should not be so ... In our view the primary [original emphasis] responsibility for ensuring good conduct and sportsmanship rests not on the Referee but on the officials of the Association who are in close contact with the players and who are able to influence them. It is they who must teach discipline - by exhortation, by training, by example. Ideally, it is only as a last resort that it should be necessary to impose it. (CLG, 1971, p. 107)

This reflected the changing expectations surrounding player self-control and responsibility for control of violence. The movement in the balance between social and self-control was also accompanied by a growing distaste for displays of violence revealing changing values about how the game should be controlled and played. Changes to the rules, and their implementation, serve to highlight this. More, and less serious, incidents were penalized, indicating a greater sensitivity toward aggressive transgressions. For instance, dissent from an offending player, after the 
referee had awarded a free, meant the free would be awarded at a point ten yards nearer that player's goal line under the 1974 rules (Lennon, 1997, p. 297). The public attitude to displays of violence also changed and was reflected in increasingly critical media reports. For instance, by the 1970s players were named in national newspapers and radio reports when dismissed by the referee during a match. Such a practice was new and demonstrates the growing intolerance and distaste for violent displays such as in this report from 1977:

Another Tipperary [the name of the team] substitute, Martin McDermott, spent only 25 minutes on the field. He was introduced at the start of the second half and was ordered off for a heavy tackle on Barry Walsh. I thought him lucky not to have marched earlier because prior to that incident I noticed him guilty of at least four tackles I considered dangerous. (Irish Press, July 4, 1977, p. 12)

This can be contrasted with an inter-county match report from a decade earlier in which four players were dismissed: "it turned out to be a rancorous affair which finished with four men cooling their tempers on the side line" (Irish Times, June 10, 1968, p. 3). Here no mention is made of any of the four players dismissed and any criticism of the players involved is relatively subdued. By the 1990s it was standard practice for journalists not only to criticise players in the match reports, but also in further follow-up articles. The tone and sentiment of these media accounts also became more judgmental and less forgiving than accounts in previous decades. For instance, one journalist, writing following an inter-county match in 1993 in which no player was sent off, felt: "I was utterly appalled at what was offered up as sport ... It is now a game from which normal standards of decency and acceptable behaviour have gone walk about" (Sunday Independent, August 1, 1993, p. 46).

These reports expressed moral outrage following physical altercations between players, which are outside the rules, and are an axiomatic feature of contemporary coverage of any Gaelic football match in which such incidents occur (see, for example, Sunday Independent Dec 23, 2007, p. 11). More recently, Nicky Brennan, the then president of the GAA, after an incident at a Gaelic football match in April 2008 where 29 players were involved in scuffles, stated "it was appalling, it was unacceptable, and I'm absolutely disgusted with it" (Irish Times, April 22, 2008, p. 22). Again, this illustrates the advance in the threshold of repugnance toward violence in that acts of indiscipline or violence, which in previous decades went unnoticed or were accepted as part of a manly game, are in the words of Dunning and Sheard (1979) "nowadays regarded as abhorrent" (p. 277).

The increasing social constraints on players, and indeed their internalisation, are also evident in the improved co-ordination and consultation between officials and the acceptance of such methods by players. Officials, players and spectators now view coordination between officials as standard within the game (see O'Sullivan, 2002, p. 92). These changes facilitated greater social observation as more offences come under the radar of officiating social functionaries, further increasing the social pressure on players 
to control their conduct. The application of technology has also been employed since the late 1980s by disciplinary committees of the GAA using video evidence to assist in the imposition of sanctions, or to identify offenders who may have escaped the sanction of disciplinary functionaries on the field (see, for example, Irish Times, May 31, 1990, p. 14). As such, the opportunities for players to engage in "unseen" violence have declined, as has the tolerance for displays of violence and indiscipline, and players have gradually developed higher levels of self-control. However, the internalisation of higher standards of self-restraint was also accompanied by a transformation in the expression of violence. Gradually, but in particular from the 1960s onwards, the nature of violence changed away from spontaneous expressive violence towards more instrumental transgressions.

\section{From Expressive to Instrumental Violence}

Since the 1960s reports of instrumental violence and the imposition of rules to address it appear to have noticeably increased. For instance, the GAA's strategic review of 1971 claimed a " 'win-at-all-costs' outlook" existed and was a key factor in indiscipline (CLG, 1971, p. 108). Media reports (see Irish Press, July 4, 1977, p. 12; September 11, 1980, p. 20) also referred to these practices suggesting an increase in their frequency, such as in the following example from the journalist Mick Dunne in his report of the AllIreland Under-21 Final of 1970. He states, there was a "tendency to pull down forwards when they approached within scoring range" and goes on to say, "This has now become such a commandment of present day football and one that pays dividends under the rules of football, that the under-21s and minors employ it as a strategy of their game" (Irish Press, October 5, 1970, p. 14). To address the problem the category of "Persistent Fouling" was added to the rules as an offence in 1974 (Lennon, 1997, p. 302). Indeed, in the intervening years debates and efforts to address "persistent fouling" repeatedly emerged (see, for instance, Irish Times, July 20, 1977, p. 3; September, 30, 2008, p.26). For instance, in 1982 the director-general of the GAA claimed persistent fouling is the "'major evil' " in Gaelic football (Irish Times, March 23, 1982, p. 3). Efforts to address this within the rules continued into the late 1990s (see Lennon, 2000, p. 131).

Dunning (1986b) contends that as a social standard of habitual self-control advances, with a similar pressure to exert greater foresight, alongside a increasing competitiveness within a sport, players became more inclined to resort to instrumental violence, i.e. the propensity for players (and teams) to use violence in a calculated manner (in specific situations) increases. Over the years the competitiveness, seriousness of involvement and increasing achievement orientation (Dunning, 1986a) within Gaelic football, even for teams competing in lower grade competitions, has grown and is evident from several areas associated with the game. For example, training schedules for players have changed dramatically.

The frequency of training in particular has increased. According to Gaelic footballer manager John O' Mahony, “[the] modern intercounty player has to do some form of training either on the field or in the gym on six out of the seven days a week at certain times of the year" (Irish Times, December 30, 2002, p.28). County teams 
increasingly adopt sports science support programs with individual players receiving nutritional counselling and fitness monitoring (Reilly \& Doran, 2001). Indeed, Watson's (1995) study on elite Gaelic footballers (whose status is amateur) indicated that they had obtained fitness levels similar to that reported for professional soccer players. Concerns about quantity of training and games played by inter-county players led the central organization of the GAA to establish a taskforce to examine the issue (see GAA, 2007).

A further illustration of the increasing competitiveness and seriousness of involvement in Gaelic football is the fact that players (and teams) are required to invoke more extensive long-term planning and strict self-control in terms of training for competitions, so as to keep-up with or surpass rival teams, which creates a doublebind spiral. This socially generated competitive pressure means players and coaches must devote greater amounts of time to physical training and mental preparation outside of matches. As the commitment of time and resources increases the pressure concomitantly advances on managers and their respective teams to deliver results. One of the effects of this unplanned but compelling process is not only for players to practice faster and more skilful play, but also to strategically engage in aggressive play within the rules and use illegal violence outside the rules during matches. As such, players have become more instrumental in their use of violence, particularly in respect of the fouling tactics in which they engage against opposing players (see GAA, 2004, p. 120). Indeed, it is these very tactics that may provoke retaliation, and in turn spill over into more violent behaviour.

However, while a general shift in the balance between affective and instrumental violence has occurred, we do not suggest that violence between players, or indeed assaults by players on referees, have altogether disappeared in the intervening years at inter-county or indeed club level. On-field violence between players on opposing teams and violence directed at officials does occasionally erupt. Gaelic football had developed a structure on the field of play involving an interdependent series of two-player contests in various parts of the pitch (defence, midfield, attack) marking each other or seeking space to avoid defenders and therefore move the ball toward the goal. In such physically close contests, strength and speed are important aspects of retaining or gaining possession of the ball. Each player is expected to resist attempts at physical domination by his opposing marking player; in such social situations, the potential for aggressive encounters remains. Consequently, player self-control on the field continues to be somewhat fragile. In addition, the GAA regulatory authorities do not exercise comprehensive disciplinary control over players and groups within the organization. The centralized regulatory authorities of the GAA, although relatively strong in comparison to previous decades (Connolly \& Dolan, 2009), have on occasions been unable to implement stricter sanctions on players for non-compliance with the rules (see Lennon, 2000, p. 142). Experimental disciplinary rules, as recommended by the GAA's Football Task Force ${ }^{9}$ in late 2004, which included a sanction of sending a player off for a period of ten minutes (a sin bin) for specific offences, were eventually abandoned in Spring 2005 (see Irish Times, February 23, 2005, p. 25) as a result of 
player and manager opposition (see Irish Times, January 4, 2005, p. 21). Thus, considerable resistance remains in attempts to impose stricter rules and more severe sanctions on players. As such, the extent to which the central disciplinary authorities of the GAA can exercise greater control over its members, in relation to violence and indiscipline, through the imposition ever-stricter sanctions on teams and individual players remains contested due to resistance towards both existing (and proposed) disciplinary sanctions by groups within the GAA.

\section{Increasing Social Interdependencies}

It is our contention then, that despite the persistence of violence within the sport of Gaelic football, the threshold of repugnance toward violence did advance and a movement in the balance between social and self-restraint in favour of the latter occurred, though not in a unilinear direction. This transformation reflects changes in the personality structure (habitus) of Gaelic football players, and people in Ireland more generally, as no sport is detached from the wider society in which it exists. In this section we explain how and why this civilizing process did not progress smoothly, but in a fragile and uneven manner. For Elias (2000) "[w] hat determines the nature and degree of such civilizing spurts is always the extent of interdependencies, the level of the division of functions, and within it, the structure of these functions themselves" (p.379). We content that over the course of the last 125 years Irish people were gradually enmeshed in longer and denser chains of interdependencies. Increased social interdependencies mean that greater numbers of people depend upon one another for the accomplishment of specific functions. More and more social functions must interlock if they are to function. Such a process leads to an inter-related and compelling process whereby people succumb to social pressure to exert greater selfcontrol and foresight over their actions. This process can be identified in the case of Ireland. ${ }^{10}$

The increasing industrialization in Britain in the nineteenth century went hand in hand with increasing commercialization and functional specialization within Irish agriculture. Growing competition between Irish farmers and those of other nations for the custom of British consumers also compelled greater mechanization of agricultural practices and the consolidation of farms into larger enterprises. This had the effect of limiting employment opportunities for the lower farming classes, such as agricultural labourers, who had to migrate to urban centres (and other countries) for employment. This urbanization process of course was further facilitated by growing trade between Ireland and Britain; urban centres served as nodes of exchange and administration. Increasing trade necessitated improved transportation networks and a more reliable security apparatus for the safe shipment of produce. Our emphasis here on urbanization is significant in that it is a principle indicator of increasing social interdependencies. More people become functionally dependent on one another for their transport, food provision, and work, indeed from the simplest to the most complex function. In the Irish nation-state as a whole the proportion of people who lived in towns of more than 1,500 people rose from thirty two per cent to fifty two 
percent between 1900 and 1971 (Vaughan \& Fitzpatrick, 1978) and to sixty one percent by 2006 (CSO, 2006). Changes in the agricultural labour force serve to highlight this too. According to selected Census of Population statistics (1861 to 2002) the proportion of the male labour force engaged in agricultural occupations remained fairly stable at between fifty and sixty per cent up to 1946 . However, by 1961 it had declined to forty three per cent and declined further to twenty per cent by 1981 and eight per cent by 2002. The importance of noting this decline is because farm life, in general, is more autarkic. Although agricultural labourers and farmers were interdependent with each other, and with other social functionaries such as agents, distributors and consumers, in their everyday life they were subject to less extensive and varied social constraints compared to those living and working in urban areas, allowing for inter-class and occupational differences. However, these social pressures for greater foresight, and correspondingly in the need to exercise greater self-restraint, spread gradually, though at a different pace, to all sections of society.

Through 1960s and onwards Ireland became even more interdependent with other nation-states. In particular, the economic and political situation became more expansive and outward looking. Irish governments sought to increase employment opportunities, to address high levels of emigration and unemployment, through attracting foreign investment. This further expanded social interdependencies as more sectors of Irish society became increasingly integrated into more complex and expanding networks of global trade and commerce. In 1951 only sixteen per cent of manufacturing output was exported, by 1988 this increased to sixty four per cent with foreign firms accounted for seventy five per cent of this (O'Malley, 1992). Ireland's ascension into the European Community in 1973 also brought new social pressures and opportunities to Irish industrialists and Irish farmers (Lee, 1989). European integration has not only economic of course, but political and cultural too. Integration within these extensive international competitive networks led to a growing pressure for more differentiated and specialised functions (occupations) within Ireland, and in turn these functions both required and further permitted greater foresight. As the division of labour expands a corresponding social pressure for more advanced levels of foresight and stricter and even levels of self-restraint is generated across all levels of society - a civilizing effect. Thus, longer and denser interdependencies shaped the changing psychic habitus of people over that period ${ }^{11}$ which in turn was reflected in the sport of Gaelic football. Interrelated with this was the gradual, but very unstable and uneven development of the state monopoly on physical violence. Lengthening chains of interdependency and a state monopolisation of violence, overall, exert a civilizing effect (Elias, 2000). However, in Ireland, this process led to rather fragile player civilizing process.

\section{The Monopolization of Violence and State Formation Processes in Ireland}

The monopolisation of violence in Ireland was a particularly fragile and uneven process which we argue moderated the development of a more even and comprehensive civilizing process. Here, we outline the uneven nature of this process and how it affected 
the development of Irish people's habitus - their way of thinking, acting and feeling particularly in relation to violence.

By the 1880s Irish society had undergone a process of agrarian class transformation (see Clark, 1978). The conflicts and tension between farmers, landholders and labourers had shifted and became predominantly disputes between landowners and tenants (farmers). Declining violence between "native", Catholic agrarian classes meant a relatively pacified social space developed and allowed attempts to pursue the regular organization of sport. It was this social context which facilitated the formation of the GAA in 1884 .

However, tensions between nationalist groups and opposing unionist groups were growing more intense by the 1890s, which also overlapped the intensifying dispute between the agrarian tenant classes and the mainly Anglo-orientated land owning classes, as well as other group distinctions along ethnic and religious lines. The changing balance of power between tenant-farmers and landlords in favour of the former was reflected in the improving power chances of the urbanized working classes in relation to their employers from the early twentieth century (see Keogh, 1982). As the working classes were often connected to the small farming classes through migration to towns and cities, they too tended to espouse a resurgent nationalism. These groups were loosely allied with some rising urban middle-class groups comprising teachers, civil servants and clerks - functional specialists that were expanding in the light of greater social interdependencies. These interdependencies simultaneously advanced mutual identification, and a more strident national identity. Increased interdependencies between the Irish social classes tended initially to exacerbate tensions and inter-class struggles also emerged. In 1913 violence erupted between urban working classes and the representatives of middle class industrialists.

At the same time, following the failures of constitutional nationalism to achieve a level of independence many members of the rising middle classes and working classes shifted their allegiances to militant nationalism and challenged the British state monopoly of violence, which was never complete in Ireland. The nationalist uprising of 1916 was followed by the War of Independence and the Irish Civil War of 1922-3. The partial success of militant nationalism in securing greater independence from Britain and in parallel with this, the sense of failure in not achieving a fully independent and united Ireland, shaped Irish people's ambivalence toward violence. Following this period, physical violence continued to be a feature of Irish society well into the twentieth century as violent confrontations between members of the opposing groups in the Civil War persisted into the 1930s (Lee, 1989). "Parliamentarization" (see Elias, 1986) in Ireland did not progress evenly due to failure of nationalists to achieve a united independent nation and the proceeding struggles, both social and symbolic, for re-unification, and over the means to accomplish this. Following the partition of Ireland after the War of Independence and the failure of nationalist groups since then to secure re-unification, tensions (and violence) between nationalists and unionists, specifically in what became known as "Northern Ireland",12 remerged throughout the twentieth century. Unionist groups sought to retain the six north-eastern counties 
within the Union with Britain while nationalist groups sought to reunite these six counties with the rest of Ireland.

Gradually violence became increasingly pushed behind the scenes. For instance, in the case of disputes between workers and employers with the growth of representative organizations acting in the name of class groups, and the relative democratization of state governance, such tensions became less violent and more prone to verbal negotiation. At the same time, the Irish state strengthened its hold on the monopolization of violence over its jurisdiction of the twenty six counties (the Republic of Ireland), though this cannot be said for British control of the six north-eastern counties (Northern Ireland), where the monopoly of violence was particularly fragile throughout the 1970s and 1980s when violence re-escalated significantly in a spiral process. This violence, to a degree, also extended to the twenty-six counties, where the Irish state's police and armed forces were required to contain the violent actions of armed nationalists and their sympathizers. The GAA suffered greatly during this period as Gaelic football is played and organized on all All-Ireland basis. Sporting facilities were damaged or destroyed and some GAA members were attacked and murdered by British forces or loyalist paramilitary groups ${ }^{13}$ (see Cronin, 1996). Gradually nationalists and unionists lessened their distrust of each other and the majority of militant groups on either side eventually gave up on relying on violence by the mid 1990s and the monopoly of force attained a relative solidity within this space too.

We document the achievement, though uneven and fragile, of a relatively stable monopoly on physical violence in Ireland as it was this process which both directly and indirectly (it permitted and facilitated greater functional specialization and lengthening chains of interdependence) exerted a civilizing effect. However, the fragile and uneven nature of this process had a moderating effect on the various social constraints progressively imposed to deter violence within the sport of Gaelic football. The use of violence in the struggle for national independence, and more importantly its partial success in achieving a level of independence, in turn created positive associations between violence and the achievement of successful, but partial, independence. This was later reflected in the continued use of violence, and ambivalence towards its use, in efforts at national unification. Thus, the use of violence in state formation in Ireland shaped the ambivalence towards violence. Thus, we contend this ambivalence served to moderate the social pressure for greater self-restraint over the control of violence within the sport of Gaelic football.

\section{Conclusion}

Over the course of the last 125 years it is our contention that the sport of Gaelic football has undergone a civilizing process (Elias, 2000). This does not mean violence no longer occurs in Gaelic football matches; rather the violence that does occur has changed and is generally of a more muted, generally less violent and more calculating form. Indeed, while violence within the sport persists, media based criticisms surrounding violence within the sport must be viewed within the context of contemporary tolerance levels 
and sensitivity towards violence within Ireland. We argue, in line with Elias and Dunning's (1986) theory, that the increasing social interdependencies both within Ireland and between Ireland and other nation-states placed greater constraints on spontaneous violent emotional displays, which in turn inculcated in people less aggressive and more controlled conduct while engaged in playing Gaelic football. However, due to the uneven, contradictory and at times reversing nature of such civilizing processes within the general development of growing social interdependencies, these changes in the culture of violence in Ireland, and consequently in the sport of Gaelic football, have been fragile, ambivalent and non-linear.

At the same time, alongside the advancing threshold of repugnance towards violence and the exertion of greater self-control and foresight, a compelling process of increasing competitiveness and seriousness of involvement also occurs. Despite a process of sportization, where rules, conventions and sanctions have increased and tightened, teams (and players) are caught in a double bind spiral of increasing competitiveness with opposing teams (and players). The result is that players are likely to resort to deliberately breaking the rules and/or resorting to instrumental forms of violence, which can lead to further violence. The inability of the centralized disciplinary authorities of the GAA to impose stricter sanctions for indiscipline due to the power and influence of groups opposed to such changes mean that struggles over the imposition of further violence control mechanisms persist.

\section{Notes}

1 The sports of Gaelic football and hurling which are governed by the GAA are known commonly in Ireland as Gaelic games.

2 Elias focused on France in particular.

3 See Dolan \& Connolly (2009) for a study on the civilizing of hurling in Ireland.

${ }^{4}$ Factions fights were ritualized brawls involving large groups of men (even up to 100) on each side (see Conley, 1999, p. 60).

${ }^{5}$ see Celtic Times, February 19, 1887, p.5, September, 10, p. 7, December 24, p. 6, for similar accounts on wrestling and handi-grips

${ }^{6}$ See letter from Robert O'Keefe to John J. Higgins dated December 18, 1914 in

Bailiúchán John J. Higgins, Leix and Ossory GAA, 1914-1917, The GAA Archive, Croke Park.

7 When the ball went over the side-line it was thrown in by a player up until 1945, after which the rules stated it must be kicked in.

8 The umpire's (these officials stood beside the goal) duty was to signal when a player scored or when the ball crossed the end line (Lennon, 1997, p. 238).

9 Within the GAA's structure a whole range of committees operate to examine rules, administration etc. Taskforces are also formed to put commendations to the operational management committee and Annual Congress.

10 See Dolan (2005) for a more detailed account of this process.

11 For a more detailed account of the development of the Irish habitus during this period, see Dolan (2005). 
12 In 1921, as a result of a treaty between the British government and the Provisional Irish government, Ireland was partitioned. Six north-eastern counties later known as Northern Ireland, within which a majority of the inhabitants wished to remain British citizens, remained under the jurisdiction of Britain.

13 For instance, Aidan McEnespie was shot dead by British soldiers on his way home from a Gaelic football match on 21st February 1988 (see The Irish Times, February 22, 1988).

\section{References}

Carey, T. (2007). Croke Park: A History. Cork: The Collins Press.

Clark, S. (1978). The Importance of Agrarian Classes: Agrarian Class Structure and

Collective Action in Nineteenth-Century Ireland. British Journal of Sociology, 29(1), 2240.

CLG. (1971). Report of the Commission on the GAA. Dublin: Gaelic Athletic Association. Conley, C. (1999). The Agreeable Recreation of Fighting. Journal of Social History, Fall, 57-72.

Connolly, J., \& Dolan, P. (2009). Organizational centralization as figurational dynamics: Movements and countermovements in an Irish sports organization. Paper presented at the European Group for Organization Studies, Barcelona, July 2-4.

Courtney, P. (Ed.). (2005). Classic All-Ireland Finals. Galway: Leinster Leader Ltd. Cronin, M. (1996). Defenders of the Nation? The Gaelic Athletic Association and Irish Nationalist Identity. Irish Political studies, 11(1), 1-19.

Cronin, M. (1998). Fighting for Ireland, Playing for England? The Nationalist History of the Gaelic Athletic Association and the English Influence on Irish Sport. International Journal of the History of Sport, 15(3), 36-56.

CSO. (2006). Census 2006. Preliminary Report. Dublin: Central Statistics Office.

De Búrca, M. (1989). Michael Cusack and the GAA. Dublin: Anvil Books.

De Búrca, M. (1999). The GAA: A history (Second ed.). Dublin: Gill \& Macmillan.

Devine, F. L. (2002). The Twenties. In T. Moran (Ed.), Stair CLG Chonnacht 1902-2002 (pp. 23-36). Carrick-on-Shannon, Co. Leitrim Carrick Print.

Dolan, P. (2005). The Development of Consumer Culture, Subjectivity and National Identity in Ireland, 1900-1980. Unpublished PhD, Goldsmiths College, University of London, London.

Dolan, P., \& Connolly, J. (2009). The Civilizing of Hurling in Ireland. Sport in Society, 12(2), 193-208.

Dunning, E. (1986a). The Dynamics of Modern Sport: Notes on Achievement-Striving and the Social Significance of Sport. In N. Elias \& E. Dunning (Eds.), Quest for Excitement: Sport and Leisure in the Civilizing Process. Oxford: Basil Blackwell.

Dunning, E. (1986b). Social Bonding and Violence in Sport. In N. Elias \& E. Dunning (Eds.), Quest for Excitement: Sport and Leisure in the Civilizing Process (pp. 224-244). Oxford: Basil Blackwell.

Dunning, E. (1999). Sport Matters: Sociological Studies of Sport, Violence and Civilization. London: Routledge. 
Dunning, E., Murphy, P., \& Williams, J. (1986). Spectator Violence at Football Matches; Towards a Sociological Explanation. In N. Elias \& E. Dunning (Eds.), Quest for excitement (pp. 245-266). Oxford: Basil Blackwell.

Dunning, E., \& Sheard, K. (1979). Barbarians, Gentlemen \& Players: A Sociological Study of the Development of Rugby Football. Canberra: Australian National University Press. Elias, N. (1978). What is Sociology? New York: Columbia University Press.

Elias, N. (1986). Introduction. In N. Elias \& E. Dunning (Eds.), Quest for Excitement: Sport and Leisure in the Civilizing Process (pp. 19-62). Oxford: Basil Blackwell.

Elias, N. (1987). The Retreat of Sociologists into the Present. Theory, Culture \& Society, 4, 223-247.

Elias, N. (1991). The Society of individuals. Oxford: Basil Blackwell.

Elias, Norbert (1993). Time: An Essay. Oxford: Blackwell Publishers.

Elias, N. (2000). The Civilizing Process: Sociogenetic and Psychogenetic Investigations (Revised Edition ed.). Oxford: Blackwell Publishers.

Elias, N., \& Dunning, E. (1986). Quest for Excitement: Sport and Leisure in the Civilizing Process. New York: Basil Blackwell.

Elias, N., \& Scotson, J. L. (1994). The Established and the Outsiders (2nd ed.). London: Sage.

Elliott, R., \& Maguire, J. (2008). “Getting Caught in the Net”: Examining the Recruitment of Canadian Players in British Professional Ice Hockey. Journal of Sport and Social Issues, 32(2), 158-176.

Fitzgerald, D. (1914). How to Play Gaelic Football. Cork: Guy \& Co. Ltd.

GAA. (1943). Minutes of Annual Congress. Dublin: GAA.

GAA. (1955). Cumann Lúitcleas Gaeoeal Ard Comairle mionturisci - 1945. Dublin: GAA.

GAA. (2004). An Chomhdháil Bhliantúil. Dublin: Gaelic Athletic Association.

GAA. (2007). Report of the Task Force on Player Burnout. Dublin: Gaelic Athletic

Association.

Garnham, N. (2004). Accounting for the Early Success of the Gaelic Athletic Association.

Irish Historical Studies, xxxiv(133), 65-78.

Guiney, D. (1976). Gaelic Football. Dublin: Gaelic Press.

Hunt, T. (2008). Sport and Society in Victorian Ireland. The case of Westmeath. Cork: Cork University Press.

Keogh, D. (1982). The Rise of the Irish Working Class: The Dublin Trade Union Movement and Labour Leadership, 1890-1914. Belfast: Appletree Press.

Lee, J. (1989). Ireland 1912-1985. Cambridge: Cambridge University Press.

Lennon, J. (1997). The Playing Rules of Football and Hurling, 1884-1995. Gormanstown, Co. Meath: Northern Recreation Consultants.

Lennon, J. (1999). A Comparative Analysis of the Playing Rules of Football and Hurling 1884-1999. Gormanstown, Co. Meath: The Northern Recreation Consultants.

Lennon, J. (2000). Towards a Philosophy for Legislation in Gaelic Games. Gormanstown, Co. Meath: The Northern Recreation Consultants. 
Lennon, J. (2001). The Playing Rules of Hurling 1602-2010; Gaelic Football 1884-2010; Hurling-Shinty Internationals 1933-2000. Gormanstown, Co. Meath: The Northern Recreation Consultants.

Liston, K. (2005). Established-outsider Relations between Males and Females in the Field of Sports in Ireland. Irish Journal of Sociology, 14(1), 66-85.

Mahon, J. (2000). A History of Gaelic Football. Dublin: Gill \& Macmillan.

Malcolm, D. (2001). "Its Not Cricket": Colonial Legacies and Contemporary Inequalities. Journal of historical sociology, 14(3), 263-282.

Mandle, W. F. (1987). The Gaelic Athletic Association and Irish Nationalist Politics, 18841924. Dublin: Gill and Macmillan.

McDevitt, P. F. (1997). Muscular Catholicism: Nationalism, Masculinity and Gaelic Team Sports, 1884-1916. Gender \& History, 9(2), 262- 284.

McTernan, J. C. (Ed.). (1984). Sligo G.A.A. A Centenary History 1884-1984. Sligo: Coiste Chontae Shligigh.

Mennell, S. (1989). Norbert Elias. New York: Basil Blackwell.

Nolan, W. (Ed.). (2005). The Gaelic Athletic Association in Dublin 1884-2000 (Vol. Vol. 1).

Dublin: Geography Publications.

O’Donoghue, N. (1987). Proud and Upright Men. Indreabhán.

O’Malley, E. (1992). Problems of Industrialisation in Ireland. In J. H.

Goldthorpe \& C. T. Whelan (Eds.), The Development of Industrial Society in Ireland.

Oxford: Oxford University Press.

O’Sullivan, J. (2002). Men in Black. Dublin: Sliabh Bán Publications.

Ó Riain, S. (1994). Maurice Davin (1842-1927). First President of the G.A.A. Dublin:

Geography Publications.

Reilly, T., \& Doran, D. (2001). Science and Gaelic football: A review. Journal of Sports

Sciences, 19, 181-193.

Sheard, K. (1997). Aspects of Boxing in the Western "Civilizing Process". International Review for the Sociology of Sport, 32(1), 31-57.

Sheard, K. (1999). A Twitch in Time Saves Nine: Birdwatching, Sport, and Civilizing processes. Sociology of Sport Journal, 16, 181-205.

Sheard, K. (2004). Boxing in the Western Civilizing Process. In E. Dunning, D. Malcolm \& I. Waddington (Eds.), Sport histories (pp. 15-30). London: Routledge.

van Bottenburg, M., \& Heilbron, J. (2006). De-Sportization of Fighting Contests: The Origins and Dynamics of No Holds Barred Events and the Theory of Sportization.

International Review for the Sociology of sport, 41(3-4), 259-282.

Vaughan, W. E., \& Fitzpatrick, A. J. (Eds.). (1978). Irish Historical Statistics: Population, 1821-1971. Dublin: Royal Irish Academy.

Watson, A. (1995). Physical and Fitness Characteristics of Successful Gaelic Footballers. British Journal of Sports Medicine, 29(1), 229-231. 